\title{
Is Canada's supply management system able to accommodate the growth of farm-direct marketing? A policy analysis
}

\author{
Patrick Mundler, ${ }^{\text {* }}$ Daniel-Mercier Gouin, ${ }^{\mathrm{b}}$ Sophie Laughrea, ${ }^{\mathrm{c}}$ and Simone Ubertino ${ }^{\mathrm{d}}$ \\ Université Laval
}

Submitted September 19, 2019 / Revised December 15, 2019, and January 10, 2020 / Accepted January 16, 2020 /

Published online May 22, 2020

Citation: Mundler, P., Gouin, D.-M., Laughrea, S., \& Ubertino, S (2020). Is Canada's supply management system able to accommodate the growth of farm-direct marketing? A policy analysis. Journal of Agriculture, Food Systems, and Community Development, 9(3), 261-279. https://doi.org/10.5304/jafscd.2020.093.023

Copyright (C) 2020 by the Authors. Published by the Lyson Center for Civic Agriculture and Food Systems. Open access under CC-BY license.

\begin{abstract}
In recent years, Canada has witnessed a rapid growth in short food supply chains. As in other countries, such marketing channels have emerged in Canada in response to a growing demand among consumers for fresh, local products. However, a unique feature of Canadian agriculture is that dairy, egg, and poultry production are under supply management. The government requirement for

a* Corresponding author: Patrick Mundler, Faculty of Agriculture and Food Sciences, Department of Agri-Food Economics and Consumer Sciences, Université Laval, Quebec; Pavillon PaulComtois, local 4423, 2425 rue de l'Agriculture; Quebec, QC, G1V 0A6 Canada; patrick.mundler@,fsaa.ulaval.ca

b Daniel-Mercier Gouin, Department of Agri-Food

Economics and Consumer Sciences, Université Laval, Quebec, Canada; Daniel-Mercier.Gouin@eac.ulaval.ca

c Sophie Laughrea, Department of Agri-Food Economics and Consumer Sciences, Université Laval, Quebec, Canada; sophie.lauhgrea@gmail.com

d Simone Ubertino, Department of Agri-Food Economics and Consumer Sciences, Université Laval, Quebec, Canada; simone.ubertino@gmail.com
\end{abstract}

producers in these sectors to purchase a quota ensures that output matches domestic demand. Until recently, though, little attention had been paid to how this system affects the development of short food supply chains in the country. The purpose of our study is to examine this emerging issue. The results of our policy analysis suggest that small farmers in Canada face multiple challenges when seeking to produce and market specialty products that are under supply management. Furthermore, the cost of entering supply-managed sectors for producers varies as each province is responsible for

Authors' Note: Implication from COVID-19

Our research was conducted before the COVID-19 outbreak. Since then, interest in short supply chains and local food has dramatically increased. Certain stakeholders discussed in this article are again asking that the supply management system be changed to allow local farms to produce eggs and chickens for their clients.

\section{Funding Disclosure}

The Center for Interuniversity Research and Analysis of Organizations (CIRANO) provided financial support for this research. 
establishing its own quota exemption limits, minimum quotas, and new entrant programs. Our study indicates that supply management policies have important implications for local and regional food system development and for food diversity in Canada.

\section{Keywords}

Farm-Direct Marketing, Food Systems, Local Food, Short Supply Chains, Supply Management

\section{Introduction}

As in other countries, Canada has witnessed in recent years a rapid growth in the practice of farmers directly marketing their products to customers through short food supply chains. According to the most recent agricultural census (Statistics Canada, 2017a), more than 24,500 farms in Canada use such marketing channels, a figure that represents $12.7 \%$ of all Canadian farms. Most direct-market farmers sell their products at the farm gate $(89 \%)$, while some also participate in farmers' markets $(22 \%)$ or distribute food boxes as part of community supported agriculture programs (CSA) (5\%).

Studies indicate that Canadian consumers attribute a wide range of benefits to short supply chains (Mundler \& Laughrea, 2016; Newman et al., 2017; Smithers, Lamarche, \& Joseph, 2008), despite remaining barriers that limit their accessibility (McIntyre \& Rondeau, 2011). Farmer's markets in Canada are notably gaining in popularity and are the most commonly studied directmarketing channel (Connell, Smithers, \& Joseph, 2008; Smithers \& Joseph, 2010; Smithers et al., 2008; Wittman, Beckie, \& Hergesheimer, 2012). Moreover, research findings suggest that short supply chains contribute to the renewal of Canadian agriculture as many new farmers rely on such local outlets to sell their products (Laforge, Fenton, Lavalée-Picard, \& McLachlan, 2018). Fundamentally, farm-direct marketing is part of a larger movement that seeks to promote the relocalization of food production (Mount et al., 2013). Indeed, various studies have explored the relationship between short supply chains and the social economy (Beckie, Kennedy, \& Wittman, 2012;
Campbell \& MacRae, 2013).

In Canada, poultry (chickens and turkeys), egg (table and hatching eggs), and dairy (cow's milk) production are under supply management. In each of these commodity sectors, quota policies ensure that supply matches domestic demand by controlling output, setting prices according to production costs, and limiting imports (Goldfarb, 2009; Painter, 2007; Schmitz \& Schmitz, 1994). As a result, Canadian farmers interested in producing supply-managed commodities are required to purchase a quota once their production volume exceeds a certain threshold. While the effect that this system has on the growth of short supply chains is considered an important research priority (Blay-Palmer et al., 2013), the topic has received relatively little attention until recently. ${ }^{1}$

Supply management in Canada has proven effective at stabilizing production and protecting farmer revenues. At the same time, it has been criticized by some for its inability to supply consumers with niche products (Amir, 2014; Legendre, 2015). Indeed, several press articles in recent years have reported on growing calls among Canadian consumers for more specialty poultry, eggs, and dairy products (marketed as organic, free-range, grassfed, antibiotic-free, heritage breed, etc.) (Ballivy, 2012; Csanady, 2015; Lamontagne, 2015; Ménard, 2015). However, according to sustainable farming advocacy groups, the rules of supply management prevent the farm sector from responding to this rising demand.

These critics point out that many farmers are interested in producing small quantities of specialty products for local markets but are unable to do so because they do not own a quota. Indeed, small farmers often struggle to enter supply-managed sectors because quotas are rarely available, expensive, or require a minimum level of output that is too high (Amir, 2014; Lamontagne, 2015; Legendre, 2015; Young \& Watkins, 2010).

The purpose of our study is to examine these various issues affecting Canada's food system. In the first section, we provide a brief overview of supply management in Canada. We also examine the ongoing debate around quota policies and high-

${ }^{1}$ With the notable exception of Young and Watkins (2010) and Mount (2017). 
light how the nature of the disagreements has shifted in recent years due to rising consumer interest for specialty food items and the growth of short supply chains. In the second section, we outline the research activities we undertook to gather information on supply management policies and programs. The results of our research are then presented in the third section. Specifically, we examine quota exemption policies and minimum quota holding requirements and analyze the programs that have been created to assist small farmers seeking to directly market specialty products. In the fourth section, we discuss the implications of our findings and the major lessons that can be drawn from recent reform experiences in Canada. Finally, we conclude by examining the future of supply management in Canada in light of the growing demand among consumers for specialty products and the rising popularity of short supply chains.

The research contribution of our study is twofold. Firstly, since each province sets its own quota policies, our study highlights the unequal playing field that faces farmers who are interested in directly marketing supply-managed goods. Secondly, we provide an in-depth analysis of the new societal challenges that currently confront Canada's supply management system. This system was historically implemented during a period of agricultural modernization and market instability. We note that the mounting calls for regulatory reform are not intended to challenge the basic legitimacy of the quota system. At the same time, the criticisms made do reflect a growing demand on the part of consumers for greater food diversity, understood here to mean a wider variety of available food items (Harvey, McMeekin, \& Warde, 2004; Thiele \& Weiss, 2003).

\section{Supply Management in Canada}

\section{The Organization of Supply-Managed Sectors}

In Canada, the federal and provincial governments have historically enacted different programs to support farmers (Schmitz, 2008). At the end of the 1960s, the idea of controlling agricultural supply through quotas emerged as a promising policy alternative to revenue support programs, which had been introduced in the post-war period. Policy- makers argued that a quota system was preferable because it would effectively safeguard farmer revenues, promote market stability, and ensure that prices adequately compensated producers without the need for further subsidies (Gouin \& Kroll, 2018; Hiscoks, 1972).

In concrete terms, supply management policies control output in a given sector and set prices so that farm production costs are covered. The fiscal burden of implementing such a program is minimal since most of the costs are borne by stakeholders within the supply chain itself (producers, processors, distributors, and consumers). In addition to protecting farm revenues, supply management also plays an effective role in stabilizing consumer prices.

Dairy farmers were the first to be included in a national quota system (1970), followed by egg (1972), turkey (1974), and chicken producers (1978). Subsequently, prices for these commodities were no longer determined by supply and demand but set using a formula that accounts for production costs. As a result, the system enables producers who hold quotas to obtain prices that are negotiated, known in advance, and guaranteed.

In exchange for this arrangement, producers in Canada are required to collectively adjust their total output in response to changes in domestic demand. When demand rises (falls) for a supply-managed commodity, the national quota is adjusted upwards (downwards), and changes are then made to each provincial allotment. Finally, the amount allocated to individual quota holders is adjusted based on their share of the provincial allotment from the preceding period (Katz, Bruneau, \& Schmitz, 2008). Usually the national quota is adjusted annually and the changes are passed down to the provinces, who then proportionally adjust the amounts held by each individual quota holder. In exceptional cases, these adjustments are made over the course of the year. As a result of these policies, agricultural commodities in Canada that are regulated through quotas are rarely exported. At the same time, access to the Canadian market is limited since import tariffs are imposed on all supply-managed goods. However, to ensure that the poultry, egg, and dairy sectors remain at least partially exposed to market forces, producers are authorized to buy 
and sell quotas (except in certain cases, such as when the allotment is a loan) (Gouin, 2001; Walker, 1968).

To implement the quota system, the producer association at the provincial level for each supplymanaged sector was given a legal mandate to distribute and manage the province's allotment. Each of these associations is also responsible for determining the maximum authorized level of output that farmers without quotas can produce, as well as the minimum production volume that is required of those who wish to obtain an allotment. ${ }^{2}$ In addition, every province has an independent regulatory agency whose role is to review the regulations proposed by producer associations, verify that the rules are being correctly enforced, and settle disagreements among stakeholders.

At its core, supply management was instituted as a way to address the problems experienced by dairy, poultry, and egg producers, who regularly faced periods of overproduction and declining prices (Doyon, 2011). As Figure 1 illustrates, supply-managed production has had to adjust to changes in demand. For instance, public concerns about cholesterol at the end of the 1980s caused dairy consumption to fall. As a result, downward adjustments were made to dairy quotas, and production contracted by $11 \%$ between 1988/89 and 1992/93. Nevertheless, since 2014, growing demand among Canadian consumers for dairy products has led to a rise in milk production.

In addition, a rise in demand for chicken from the mid-1980s onwards has led to a significant increase in output. Since the beginning of the 2000 s, egg production has also expanded rapidly. In response to these favorable market trends, the associations of chicken, turkey, and egg producers in each province have distributed new allotments to individual quota holders. These allotments are generally given (not sold) to producers and immediately acquire a market value (since they can be traded). However, in some cases (e.g., Quebec's egg producer association), they are lent out and remain the property of the association.

To summarize, supply management policies in Canada were enacted in order to (1) set prices according to production costs, (2) establish a quota system that could meet the needs of the domestic

\section{Figure 1. Evolution of Production in Sectors Under Supply Management, Canada, 1976-2017}

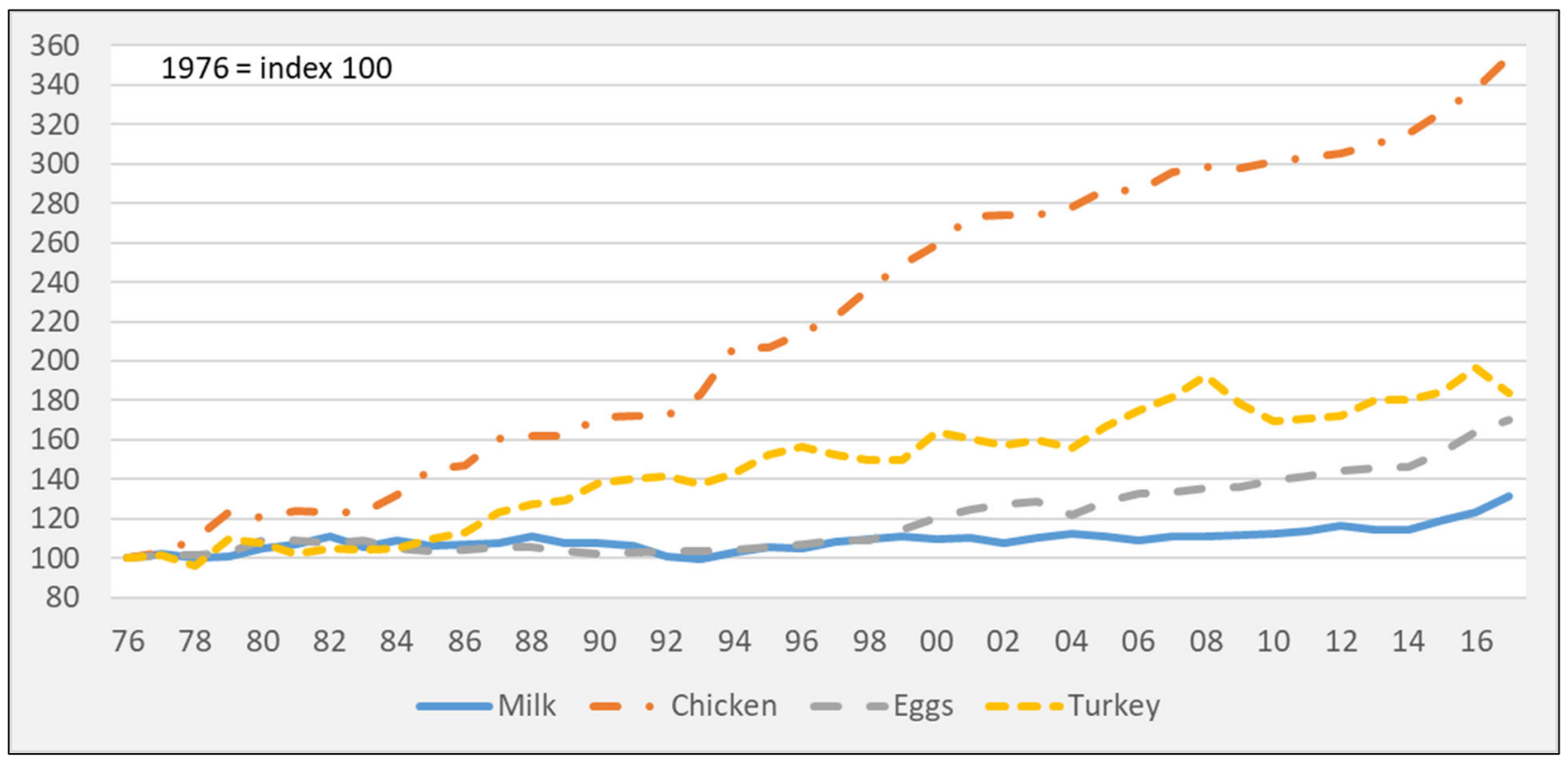

Note: The data for chicken production covers both chickens and laying hens. Egg production includes table and hatching eggs. Sources: Statistics Canada (2017b, 2017c, 2017d); our calculations.

2 The producer associations enforce their regulations through marketing boards (Royer, Ménard, \& Gouin, 2015). 
market, and (3) control imports. These policies were the result of a social compromise established in Canada in the 1970s. In practical terms, the quota system reflects a willingness on the part of Canadian consumers to accept prices that adequately compensate producers by limiting their exposure to foreign competition and the volatility of world markets. In exchange, supply-managed farmers agree to meet the needs of the internal market and satisfy the quality expectations of Canadian consumers.

\section{A Contested System}

While supply management is today a unique feature of Canadian agricultural policy, it is not without its critics. Some argue that the use of quotas leads to markets distortions, protects inefficient producers (Veeman, 1982), hinders restructuring efforts, reduces sectoral competitiveness, and prevents producers with lower production costs from expanding their output (Hall Findlay, 2012). Moreover, certain studies suggest that supply management in Canada places a heavy burden on consumers, especially low-income households, due to the inelastic nature of demand for supply-managed products (Cardwell, Lawley, \& Xiang, 2015; Desrochers, Geloso, \& Moreau, 2018). Quota policies are also criticized by some for hindering the ability of producers and food processors to export their products (Barichello, Cranfield, \& Meilke, 2009; Carter \& Mérel, 2016). Finally, it is argued that Canada's defense of supply management weakens its negotiating position during international trade talks and closes off export opportunities for other products, including food items that are not regulated by quotas (Hall Findlay, 2012).

The cost of purchasing a quota also uses up capital that could have been productively invested elsewhere on the farm. Some researchers suggest that this discourages new farmers from entering supply-managed sectors and lowers farm productivity. (Moreau, 2017; Richards, 1996). Furthermore, given the significant decline in the number of dairy producers in Canada, critics contend that the system fails to protect small farms and that quotas are increasingly concentrated in the hands of a few producers (Hall Findlay, 2012).

At the same time, other studies indicate that supply management offers more advantages than drawbacks, including for Canadian consumers. Indeed, various authors argue that criticisms of quota policies overlook the fact that agricultural markets are inherently unstable, given that food prices are more volatile than output (Boussard, Gerard, Piketty, Ayouz, \& Voituriez, 2006; Gouel, 2010; Graddy-Lovelace \& Diamond, 2017). Also ignored is the fact that food supply chains are often dominated by stakeholders capable of imposing their own terms and conditions on producers. (Royer, 2008). Consequently, if the price for a primary agricultural product falls, the reduction is not automatically passed along to the consumer. Instead, the difference is often captured, to a greater or lesser extent, by processors and distributors, depending on their level of market power (Boston Consulting Group, 2015). Furthermore, research findings indicate that consumer prices for supply-managed products are sometimes cheaper in Canada compared to other countries, depending on the product category and the value of the Canadian dollar, among other factors (Doyon, Bergeron, \& Tamini, 2018). As well, it is argued that import restrictions on eggs, dairy, and poultry products do not weaken Canada's position during international trade talks since the country has many other market opportunities that can be presented to prospective trading partners (Mussell, 2012).

Other studies have also found that supply management does not hinder sectoral development but rather, creates a stable environment for investment (Tamini, Doyon, \& Zan, 2018). In addition, it is worth noting that Canadian farms in supplymanaged sectors are, on average, considerably smaller than those in New Zealand and the United States, where quotas are not used. For instance, the average number of cows per dairy farm in Canada is 85 , which is considerably lower than in the United States, where the average exceeds 230 (Mundler \& Ruiz, 2018). This suggests that supply management has been successful in protecting the viability of family farms and rural communities (Muirhead, 2017).

Indeed, various studies have emphasized the importance of maintaining the agricultural fabric of rural areas and of protecting the economic, social, and environmental role of farmers (Boody et al., 
2005; Bowler \& Ilbery, 1999). In this context, supply management does not so much encourage inefficient small-scale farming as it preserves a dynamic form of agriculture. Thus, the policy is, beneficial for rural communities and leads to the creation of numerous services that supply-managed farmers and their households can rely on, such as garages, salesrooms, grocery shops, financial service centers, and community gathering places. (Muirhead, 2017). In this way, supply management helps shape the rural landscape by maintaining a strong agricultural presence in regions where soils are not fertile enough to grow crops intensively (Ruiz \& Parcerisas-Benede, 2017).

\section{The Growth of Short Food Supply Chains and the Changing Nature of the Debate}

The debate over supply management has generally centered around the question of whether it is economically efficient. However, new questions are being raised in Canada about the role that the quota system plays in rural development. Promoters of farm-direct marketing argue that the system prevents specialty farmers from selling small quantities of supply-managed products to consumers in local niche markets. At the same time, the goal of these critics is not to dismantle supply management, but rather to push for reforms that address the growing desire among Canadian consumers for specialty products and direct marketing relationships (Laforge et al., 2018; Mount, 2017).

We note that Canada is the only country that still maintains supply management policies. Consequently, it is difficult for comparisons to be made with other countries. In addition, the potential impact of quotas on the growth of farm-direct marketing and specialty products was not a topic of discussion in those countries that did adopt supply management. Furthermore, Canada was the only country to supply manage chicken and egg production. Moreover, the current debate in Canada over whether to loosen regulatory restrictions mostly focuses on these two commodities, which explains why little research has been conducted on the topic outside the country.

In contrast to many European countries, the practice of farm-direct marketing in Canada is a more recent phenomenon and was not part of the agricultural landscape when supply management policies were introduced. In the dairy sector, for instance, rising consumer demand for specialty cheeses has led to the growth of artisanal cheesemaking on farms, especially in Quebec. However, regulations in most provinces set the minimum quota at $10 \mathrm{~kg}$ of butterfat $(\mathrm{BF})^{3}$ (equivalent to roughly 80,000 annual liters of milk), making it difficult for producers to start small dairy farms. Policymakers established these minimum quota requirements as a way to boost productivity in the dairy sector and ensure a cost-effective collection of milk across each province. Nevertheless, the rules enacted fail to account for the recent development of small-scale artisanal cheese production. While only a small fraction $(0.4 \%)$ of dairy (cow's milk) farms process and directly market their own products, many small-scale producers make their own cheeses from sheep or goat's milk. Since these dairy categories are not regulated by quotas, they represent a more feasible production option for small farmers and new entrants (Mundler et al., 2017).

Ultimately, the growth of farm-direct marketing alongside Canada's supply management system raises new challenges for policymakers. Regulatory officials are increasingly under pressure to accommodate the rising demand for specialty products in short supply chains (Mount, 2017; Stewart \& Dong, 2018; Young \& Watkins, 2010). There are also growing calls for policy-makers to facilitate new entrants from different backgrounds who are looking to supply these emerging niche markets (Laforge et al., 2018). Consequently, the debate over supply management has shifted away from the question of whether it should be abolished for economic reasons. Instead, advocates for reform maintain that quota regulations should evolve in order to promote equity, foster agricultural renewal, and respond to changing consumer tastes. Such reforms, they argue, will

\footnotetext{
${ }^{3}$ Dairy quotas are measured in terms of $\mathrm{kg}$ of $\mathrm{BF} /$ day. The level of daily BF content can vary, depending on different factors, but one $\mathrm{kg}$ is roughly equivalent to the output of one dairy cow.
} 
enable supply management to become once again an effective tool for rural development (Girouard, 2014; Laforge et al., 2018; Legendre, 2015; Mount, 2017).

\section{Materials and Methods}

To better understand how the governance of Canada's quota system affects the ability of small farmers to produce and directly market supply-managed commodities, we gathered information from various stakeholders at the provincial level. The research undertaken focused specifically on three key areas of interest:

- The maximum amounts that farmers can produce without a quota and the reasons behind these limits;

- The minimum output that farmers are required to produce if they wish to purchase a quota; and

- The reforms enacted by certain provinces to support new entrants who wish to directly market small production volumes.

In total, we carried out 19 semistructured interviews by telephone with representatives of industry, producer associations, and government ministries in three Canadian provinces (British Columbia, Ontario, and Quebec). We focused on these provinces because, in recent years, they were required to change their policies to accommodate direct-market farmers. Also, in all three provinces, there are large numbers of farmers who practice direct marketing (in total, these farmers represent $76 \%$ of all Canadian producers who sell through short supply chains). As well, we contacted each active provincial producer association in Canada (37 in total) by email or phone to obtain additional information on current quota regulations. The data presented in the following section was accurate as of December 31, 2016.

\section{Results}

\section{Quota Exemption Levels}

The producer associations in each province determine the maximum level of supply-managed output that farmers can produce without needing to purchase a quota. Production within these limits is intended for farm household consumption and not for sale, although selling is not prohibited. However, the exact volumes that are sold without a quota cannot be determined since the producers who do so are not required to declare their output. Nevertheless, we show later on with the cases of Ontario and British Columbia that these sales most likely represent less than $1 \%$ of chicken and egg products sold in Canada.

With the average decline in the size of Canadian families, certain provinces decided to tighten their exemption rules. For instance, in the egg sector, Quebec reduced the ceiling from 249 to 99 hens (Mundler et al., 2017). Nevertheless, a flock of 99 hens (each one producing almost one egg per day) still largely exceeds the consumption needs of a current family of four or five-just as 249 hens surpassed the needs of larger farm households in the past. Thus, it is not clear whether the decision to impose tighter restrictions was motivated by changing family demographics. In most cases, the provinces seek to give farmers the option to produce small quantities for domestic (household) consumption and local sales. Later on, we discuss quota exemption policies in the context of direct marketing.

Table 1 shows the maximum outputs allowed, as well as the percentage of farms in each province that practice farm-direct marketing. As can be seen from the data, the exemption ceiling for chicken production varies widely, from 99 birds in Newfoundland and Labrador to 2,000 birds in Alberta. There are also large differences in the maximum flock size for turkeys, although less so for laying hens. We note that none of the provinces authorize dairy production without a quota except Alberta, which allows farmers to produce up to 50 liters/day as long as the milk is processed on the farm.

Table 1 also reveals that the least restrictive quota exemptions are found in the provinces where farm-direct marketing is less commonly practiced, namely Alberta, Manitoba, and Saskatchewan. According to the stakeholders we interviewed, this could be due to the strong presence of Hutterite colonies in these three provinces $(96 \%$ of the 370 colonies in Canada are 
Table 1. Quota Exemption Limits and Percentage of Farms that Practice Direct Marketing

\begin{tabular}{|c|c|c|c|c|c|}
\hline & Chicken a & Turkey a & Egga & $\begin{array}{c}\text { Dairy } \\
\text { (L/day) }\end{array}$ & $\begin{array}{l}\text { Percentage of farms } \\
\text { that report practicing } \\
\text { direct marketing }\end{array}$ \\
\hline Alberta & 2,000 & 300 & 300 & 50 & 5.1 \\
\hline British Columbia & $200(2,000)$ & $49(300)$ & 99 (399) & 0 & 32.3 \\
\hline Prince Edward Island & 500 & $\mathrm{n} / \mathrm{a}$ & 299 & 0 & 14.4 \\
\hline Manitoba & 999 & 99 & 300 & 0 & 6.1 \\
\hline New Brunswick & 200 & 25 & 199 & 0 & 22.1 \\
\hline Nova Scotia & 200 & 25 & 200 & 0 & 23.6 \\
\hline Ontario & $300(3,000)$ & 50 & $99(500)$ & 0 & 15.1 \\
\hline Quebec & 300 & 25 & $99(500)$ & 0 & 18.9 \\
\hline Saskatchewan & 999 & 99 & 300 & 0 & 3.8 \\
\hline Newfoundland and Labrador & 99 & $\mathrm{n} / \mathrm{a}$ & 99 & 0 & 34.2 \\
\hline
\end{tabular}

aThe chicken, turkey, and egg columns indicate the maximum number of chickens, turkeys, and laying hens, respectively, that farmers can raise without a quota. The figures in parentheses either indicate the maximum level of production allowed with a direct marketing permit (which we discuss later on) or represent grandfathered provisions that benefit only a limited number of producers.

Sources: The data in the first four columns were gathered by the authors and updates the previous findings of Young \& Watkins (2010) and Girouard (2014); the data in the last column were sourced from Statistics Canada (2017a).

located in Alberta, Manitoba, and Saskatchewan). ${ }^{4}$ It is thus possible that the exemption levels are set high in order to respect the communal arrangements of these colonies. At the same time, in British Columbia, where almost one in three farms pursue direct marketing, special programs have been created that give poultry and egg farmers permits to produce over the exemption limits for local markets. Similar programs have been set up for chicken and egg producers in Ontario and for egg farmers in Quebec (we examine these programs further on).

\section{Quota Procurement Rules}

In addition to setting the exemption limits, the provincial producer associations specify the minimum output levels that farmers are required to meet if they wish to own a quota (Table 2). In the case of poultry, it is difficult to compare minimum quotas because Quebec measures production in square meters, whereas the other provinces use $\mathrm{kg}$ of live weight. As well, depending on the province, poul- try output is measured annually or by the production cycle (which lasts eight weeks). We note that Alberta is the only province that does not impose a minimum quota in any of the four sectors under supply management.

Table 2 also indicates that the minimum quota for a supply-managed commodity varies widely from one province to another. Even within a province, one sector might require that producers purchase a minimum quota, whereas another sector might not specify a base amount. Since many producers who directly market their own products run small farms, these regulatory differences affect their ability to enter certain supply-managed sectors. For instance, in Nova Scotia, it is theoretically impossible to produce between 200 chickens (the quota exemption ceiling) and 117,500 chickens (the minimum quota), meaning a farm has to stay small or become very large. It is also difficult to process cheese or yogurt on a small dairy farm since the minimum quota is generally set at $10 \mathrm{~kg}$ of $\mathrm{BF} /$ day, which roughly corresponds to the milk output

\footnotetext{
${ }^{4}$ According to the Canadian Encyclopedia, in 2016, there were 175 colonies in Alberta, 110 in Manitoba, and 70 in Saskatchewan (Ryan, 2013).
} 
Table 2. Minimum Quota Holding Requirements

\begin{tabular}{|c|c|c|c|c|}
\hline & Chicken & Turkey a & Eggs & Dairy \\
\hline Alberta & No minimum & No minimum & No minimum & No minimum \\
\hline British Columbia & No minimum & No minimum & 400 hens & $4.1 \mathrm{~kg}$ of $\mathrm{BF} / \mathrm{day}$ \\
\hline Prince Edward Island & No minimum & $\mathrm{n} / \mathrm{a}$ & No minimum & $10 \mathrm{~kg}$ of $\mathrm{BF} /$ day \\
\hline Manitoba & $\begin{array}{l}30,000 \mathrm{~kg} / \text { cycle (roughly } \\
97,500 \text { chickens/year) }\end{array}$ & $60,000 \mathrm{~kg} /$ year & 500 hens & $10 \mathrm{~kg}$ of BF/day \\
\hline New Brunswick & No minimum & No minimum & No minimum & $10 \mathrm{~kg}$ of BF/day \\
\hline Nova Scotia & $\begin{array}{l}235,000 \mathrm{~kg} / \text { year } \\
\text { (roughly } 117,500 \text { chickens) }\end{array}$ & $71,400 \mathrm{~kg} /$ year & No minimum & $10 \mathrm{~kg}$ of BF/day \\
\hline Ontario & $\begin{array}{l}182,000 \text { kg/year } \\
\text { (roughly 91,000 chickens) }\end{array}$ & $2,000 \mathrm{~kg} /$ year & No minimum & $10 \mathrm{~kg}$ of $\mathrm{BF} /$ day \\
\hline Quebec & 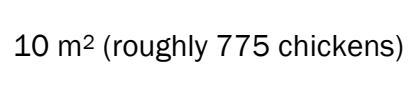 & $\begin{array}{l}\text { No minimum; } 50 \mathrm{~m}^{2} \\
\text { (roughly } 3,000 \mathrm{~kg} / \text { year) }\end{array}$ & No minimum & $10 \mathrm{~kg}$ of BF/day \\
\hline Saskatchewan & $\begin{array}{l}38,940 \text { kg/cycle (roughly } \\
143,000 \text { chickens/year) }\end{array}$ & No minimum & No minimum & No minimum \\
\hline $\begin{array}{l}\text { Newfoundland and } \\
\text { Labrador }\end{array}$ & No minimum & $\mathrm{n} / \mathrm{a}$ & No minimum & 500 liters/day \\
\hline
\end{tabular}

a Regarding turkey production: In Quebec, there is no minimum purchase requirement if a quota is bought through the province's centralized trading platform. If a farmer buys a quota directly from another producer, the minimum amount is $50 \mathrm{~m}^{2}$. Prince Edward Island does not have an active producer association, although the regulations needed to create one are in place. In addition, Newfoundland and Labrador does not participate in Canada's supply management system for turkeys.

Sources: The data were gathered by the authors and updates the previous findings of Young \& Watkins (2010).

from 10 cows.

As well, the financial cost of purchasing a quota presents an additional entry barrier for many producers. Generally speaking, quota prices vary between provinces. In the dairy sector, the producer associations in Nova Scotia, Prince Edward Island, Ontario, and Quebec responded to rising milk quota prices by capping the per-unit value at $\$ 24,000 .^{5}$ In the case of New Brunswick, a price ceiling of $\$ 25,000$ was instituted. Dairy quota prices in the remaining provinces are determined through supply and demand. In February 2019, the price of a milk quota in Canada ranged from $\$ 24,000$ (the lowest price ceiling) to $\$ 40,040$ in Alberta. ${ }^{6}$ For producers, the cost of purchasing a quota is equal to the minimum output requirement multiplied by the price for a quota unit. ${ }^{7}$

In the egg sector, the price for a single laying hen quota varied between $\$ 245$ and $\$ 350$ at the end of 2016, depending on the province. As we mentioned, it is difficult to compare poultry quotas across Canada since the provincial producer associations use different units of measurements. However, by converting the different values to annual $\mathrm{kg}$ of live weight, we estimate that chicken quotas at the end of 2016 were priced between $\$ 3.56 / \mathrm{kg}$

${ }^{5}$ All figures are in Canadian dollars.

${ }^{6}$ http://lait.org/leconomie-du-lait/statistiques/

${ }^{7}$ We remind the reader that dairy quota units are expressed in $\mathrm{kg}$ of daily BF. One $\mathrm{kg}$ of quota is roughly equal to the output of one dairy cow. If the minimum quota is $10 \mathrm{~kg}$ of $\mathrm{BF} /$ day (as is the case in most provinces, see Table 2) and the price of a single unit of quota is $\$ 25,000$, the minimum entry cost for a producer is $\$ 250,000$. To produce a hectoliter of milk, a farmer will spend $\$ 235$ in quota, while the price per hectoliter is roughly $\$ 70$. A farmer will thus need to produce milk for a little more than three years to pay off the quota, leaving aside other production costs. 
and $\$ 10.85 / \mathrm{kg}^{8}{ }^{8}$ We also estimate that turkey quotas during the same period were valued between $\$ 3.08 / \mathrm{kg}$ and $\$ 7.64 / \mathrm{kg}$.

Each province has programs in place that support new farmers by giving or lending them special quotas. For example, Quebec's association of egg producers allocates lifetime quotas of 6,000 laying hens to one or two new producers each year. In some provinces, priority is given to certain regions or production methods (such as certified organic). However, in many cases, the programs fail to meet the needs of new entrants, many of whom are interested in directly marketing small quantities of supply-managed products (Young \& Watkins, 2010). Furthermore, only a small number of new producers each year benefit from these programs. This is because most of the increases in provincial allotments due to rising demand are freely allocated to farmers who already own quotas. This is due to the fact that quota holders are the ones who fix the quota procurement rules within the producer associations that represent them and that manage the system. Consequently, between 2005 and 2015, only $7 \%$ and $6.9 \%$ of new chicken and hen quotas respectively were allocated in Quebec to beginner farmers (Mundler et al., 2017).

This brief overview of provincial quota regulations highlights the many difficulties faced by small farmers looking to produce supply-managed commodities for niche markets. Moreover, since quota policies are enacted at the provincial level, the cost of entry for producers varies depending on the province, while producer prices are generally the same across Canada (which is considered to be a single market). Entry barriers are especially high for prospective chicken and turkey farmers, owing to the strict minimum quota requirements in several provinces. Setting the exemption limit too low also compromises the ability of small farmers to supply local markets. For instance, in the egg sector, most provinces do not impose a minimum quota, so the starting level is usually determined by the exemption ceiling, which, in several provinces (Quebec, Nova Scotia, and Newfoundland and Labrador), is limited to 99 hens. Producers in these provinces could theoretically purchase an allotment to grow their production, but, since quota prices are elevated (between $\$ 245$ and $\$ 400$ for a laying hen), the profitability of such a purchase is limited.

Finally, we note that most provinces set the minimum quota for dairy production at $10 \mathrm{~kg}$ of daily BF (equivalent to roughly 10 cows). With the notable exception of Alberta, farmers without quotas are not authorized to produce limited quantities of milk. Nevertheless, Alberta and Saskatchewan do not specify a minimum quota amount, meaning that producers in either province who want to start small dairy farms could theoretically do so by purchasing a small allotment. This avenue is likewise open to producers in British Columbia, since the province's minimum quota is set at only $4.1 \mathrm{~kg}$ of $\mathrm{BF} /$ day. As we explain in the following section, British Columbia's dairy association also created a program to assist small farmers looking to manufacture and market their own dairy products.

\section{Making Room for Short Supply Chains: The Diverging Reform Paths Between Provinces}

In response to changes in consumer demand, British Columbia, Ontario, and Quebec have recently implemented policy reforms to support small farmers who wish to market supply-managed products through short supply chains. Theoretically, Canada's supply management system could evolve in different ways to accommodate small-scale specialty producers (Young \& Watkins, 2010). In Figure 2, we organize these various policy options into four categories. Three of these have been enacted; the fourth is possible but has not been tried.

Options A and B accommodate new farmers within the quota system. Under both scenarios, the producer association in question administers the new policy and sets the rules. In contrast, options $\mathrm{C}$ and $\mathrm{D}$ enable producers to market their products outside the quota system. The easiest solution (option D) is to raise the quota exemption ceiling. Another possible approach would be to change the legislation so that certain markets or products are

\footnotetext{
${ }^{8}$ In the case of Quebec, chicken quota trading resumed in April 2019, following a nine-year moratorium, so our calculation is based on prices for that month. With the resumption of trade, the quota price increased to $\$ 1,850$ per square meter of production (equivalent, on average, to 77.5 birds annually). In other words, a chicken weighing $2.2 \mathrm{~kg}$ was priced at roughly $\$ 10.85 / \mathrm{kg}$.
} 


\section{Figure 2. Supply Management Reform Options}

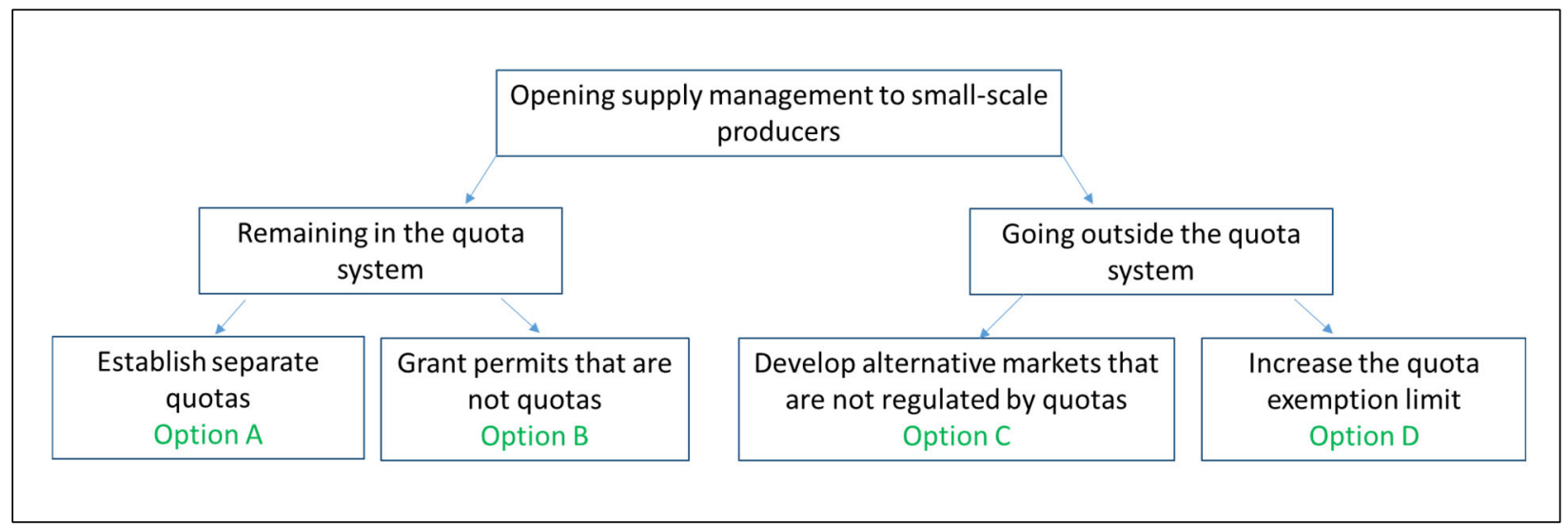

exempt from supply management rules (option C). ${ }^{9}$

Table 3 presents the various programs introduced in British Columbia, Ontario, and Quebec to accommodate small farmers in short supply chains and the corresponding policy option that each program reflects. As can be seen, the producer associations mostly favored options $\mathrm{A}$ and $\mathrm{B}$ as it enables them to maintain regulatory control over the development of local specialty markets. The only policy exception can be found in Quebec where the quota exemption limit for chickens was increased from 100 to 300 birds in July 2019 (option D) (RMAAQ, 2019).

Table 3. Outline of the Programs Introduced to Support Small Producers in Short Supply Chains (and the Corresponding Policy Option)

\begin{tabular}{lcccc}
\hline & Chicken & Turkey & Eggs & Dairy \\
\hline British Columbia & $\begin{array}{c}\text { Permit Growers Program } \\
\text { (B) }\end{array}$ & $\begin{array}{c}\text { Direct Vendor } \\
\text { Program (B) }\end{array}$ & $\begin{array}{c}\text { Small Lot Program } \\
\text { (B) }\end{array}$ & $\begin{array}{c}\text { Cottage Industry } \\
\text { Program (A) }\end{array}$ \\
\hline \multirow{3}{*}{ Ontario } & $\begin{array}{c}\text { Artisanal Chicken } \\
\text { Program (B) }\end{array}$ & & \\
\cline { 2 - 4 } & $\begin{array}{c}\text { Local Niche Markets } \\
\text { Program (A) }\end{array}$ & & \\
\hline Quebec & $\begin{array}{c}\text { Increase in the quota } \\
\text { exemption level from } \\
100 \text { to 300 chickens (D) }\end{array}$ & & $\begin{array}{c}\text { Support program for } \\
\text { beginner farmers focused } \\
\text { on direct marketing (B) }\end{array}$ \\
\hline
\end{tabular}

${ }^{9}$ This approach has not been tried for the moment. However, the provision does exist in certain regulations. For instance, in Quebec, Article 63 of the Act Respecting the Marketing of Agricultural, Food and Fish Products stipulates that "a joint plan does not apply to sales made directly by a producer to a consumer. Nevertheless, the Régie [the province's administrative tribunal for agriculture] may, by regulation, on the conditions it determines, subject such sales to any provision of a plan, by-law, homologated agreement or arbitration award if it is of the opinion that such sales seriously affect their application." In this sense, the quota exemption ceilings can be justified on the grounds of the second half of Article 63, although this legal interpretation is challenged by different stakeholders (RMAAQ, 2019). 
quota (RMAAQ, 2017), a figure that represents almost a quarter of all producers in Quebec. As a result, the province's poultry association has expressed concern that a large number of these farmers will increase their output if the quota exemption rules are relaxed. We later show that such fears are largely misplaced.

As Table 3 indicates, British Columbia pursued options A (for dairy) and B (for poultry and eggs). Reforms began in 2003 after the British Columbia Farm Industry Review Board (the province's agricultural regulatory agency) instructed the associations of chicken and turkey producers to revise their quota exemption policies (BCFIRB, 2005). Subsequently, two new programs were created that now give small farmers special permits to raise up to 2,000 chickens or 300 turkeys for farm-direct marketing purposes. Producers interested in joining either program must first register and are required to follow animal care, food safety, and biosecurity regulations. Nevertheless, participating farmers do not pay fees to the province's turkey or chicken producer associations (which, for quota holders, is set at $\$ 0.019$ per $\mathrm{kg}$ of live weight). In 2016, 182 chicken permits were distributed to farmers in the province, who raised a total of 73,266 birds (with an average flock size of 403 birds). This output represented $0.08 \%-0.09 \%$ of British Columbia's total chicken production. In the same year, turkey permits were given to 42 farmers, each of whom raised, on average, 162 birds. The total output from this program was equivalent to $0.15 \%$ of the province's turkey quota.

In British Columbia's egg sector, a similar program was implemented that gives small-scale producers permits to raise up to 399 hens without needing a quota. At the end of 2015, the program was limited to 50 permits, and registered farmers are required to produce eggs that are certified organic. The province's egg producer association estimated that permit holders raised, on average, 350 hens and produced a total of 445,200 dozen eggs, a figure that represents $0.56 \%$ of British Columbia's egg quota.

While most Canadian provinces impose a minimum dairy quota of $10 \mathrm{~kg}$ of $\mathrm{BF} /$ day, in British
Columbia the minimum is set at $4.1 \mathrm{~kg}$. Furthermore, in 2005, the province's dairy association created the Cottage Industry Program to facilitate the small-scale production of farm-manufactured dairy products. Under the program, participating farmers are given a free quota between $4.1 \mathrm{~kg}$ and $27.5 \mathrm{~kg}$ of $\mathrm{BF} /$ day. The allotment is non-transferable during the first 15 years, and producers are required to process their own milk. In 2014, the program had four participants.

In the case of Ontario, sustainable farming advocacy groups in the early 2010s pushed strongly for chicken quota regulatory reforms. Two organizations in particular (Sustain Ontario and Practical Farmers of Ontario) led public campaigns, lobbied officials, and filed lawsuits against the provincial government and the Chicken Farmers of Ontario (CFO) (the province's association of chicken producers) in an attempt to increase the quota exemption limit from 300 to 2,000 chickens. In 2010, roughly 13,000 producers without quotas were raising chickens with an average flock size of 75 birds. ${ }^{10}$ The total output from these producers represented $0.4 \%$ of Ontario's chicken quota in 2011.

Despite the efforts of advocacy groups, the exemption ceiling in Ontario for chickens was kept at 300 birds. However, in 2015, after a series of consultations with stakeholders across the province (Bryan Boyles \& Associates, 2015), the CFO agreed to create new programs and make changes to existing ones. Subsequently, in 2016, the Artisanal Chicken Program was launched, which gives producers permits to grow between 600 and 3,000 birds annually. By the end of its first year, the program had issued 103 permits to farmers who proceeded to raise, on average, 1,500 chickens. Unlike the program in British Columbia, participating farmers in Ontario pay an annual fee to the chicken producer association ( $\$ 0.036$ per chick), in addition to paying for the permit ( $\$ 0.20$ per chick). However, we note that, in both provinces, the total output from permit holders as a percentage of provincial chicken production was roughly similar (between $0.08 \%$ and $0.09 \%$, depending on the weight of the chickens).

10 https://www.ontariochicken.ca/Programs/FamilyFoodProgram.aspx 
The permit programs for chicken growers in Ontario and British Columbia both reflect policy option B. However, the CFO also pursued option A by setting up the Local Niche Markets Program, which grants special quotas to farmers who are interested in supplying local markets with specialty products. In total, $5 \%$ of the annual increase in provincial production is allocated to this program along with the Artisanal Chicken Program.

In Quebec, the association of egg producers chose option B by introducing a five-year pilot program that supports farmers who practice direct marketing. Every year since 2016, the program distributes five new permits, which enable recipients to raise up to 500 laying hens. The permits are non-transferable, and the program targets producers who sell their products through CSA programs, online platforms (marchés virtuels), or farmers' markets. In addition, participating producers are forbidden from selling to restaurants or grocery stores and are not allowed to own a quota.

Despite these changes, various advocacy groups in Quebec argue that the reforms do not go far enough. As a result, in 2018, a farmer organization (Union paysanne) requested that the province's administrative tribunal for agriculture (RMAAQ) give producers without quotas the right to raise up to 2,000 chickens, 300 turkeys, and 300 hens (an outcome that would correspond to policy option $\mathrm{D}$ ). The tribunal denied the request to raise the exemption ceilings for turkeys and laying hens. However, it did agree to increase the allowable limit for chickens from 100 to 300 birds (RMAAQ, 2019) and to put in place a five-year pilot project, similar to the one created in 2016 by the association of egg producers. The new program will give 10 producers per year the right to grow and directly sell up to 2,000 chickens. Thus, at the end of the five-year period, 50 farmers will have been issued permits as part of this pilot project.

\section{Discussion}

Originally conceived as a mechanism for stabilizing markets for certain agricultural commodities, Canada's supply management system today faces new challenges due to changes in societal views about agriculture and rising demands for greater food diversity. Since the beginning of the 2000 s, short supply chains have become increasingly popular sales points for consumers interested in fresh, local, farm-made products (Håkansson, 2015; Pearson et al., 2011; Van der Ploeg, Jingzhong, \& Schneider, 2012). Furthermore, many new producers, who often have a different vision of what it means to be a farmer, rely on these direct-marketing channels to sell their products (Laforge et al., 2018; Milone \& Ventura, 2019).

At the same time, there are growing concerns that supply management leads to product standardization, especially in egg and poultry production. In Mount (2017), an interviewed stakeholder from Ontario's chicken sector described a "cookie-cutter" system in which 1,100 supply-managed farmers "produc[e] the exact same product: same genetics, same feed, same housing facilities-you have a monoculture of chicken happening" (p. 155). While product standardization is not unique to supply-managed sectors, the quota rules in place leave little room for farmers who might wish to adopt new production and marketing practices. This problem is compounded by the fact that the investment costs needed to start production under supply management are considerable and even more so when a minimum quota is required. Furthermore, the programs that do distribute quotas to new entrants only benefit a limited number of farmers who are selected by the producer associations and receive a small percentage of new allotments (Mundler et al., 2017; Young \& Watkins, 2010). Consequently, many producers engaged in direct marketing turn to other categories of livestock (e.g., ducks, geese, quails) or process their own dairy products using sheep or goat's milk, which is not under quota. However, farmers often have difficulty marketing such products due to lower demand.

As we previously illustrated, the quota exemption limits set by the provinces vary widely. For instance, a farmer in Alberta without a quota can raise 20 times the number of chickens that a farmer can in Newfoundland and Labrador (see Table 1). The push by certain advocacy groups in the most restrictive provinces to reform the system is prompted by this uneven regulatory playing field.

In response to these demands, some of the provinces where farm-direct marketing is more de- 
veloped (British Columbia, Ontario, and Quebec) chose to implement certain changes. Overall, two lessons can be drawn from these reform experiences. First, when policies are enacted to accommodate small producers, the resulting output is marginal compared to the volumes of production under quota. In concrete terms, the additional amounts that have been put into circulation represent less than $0.1 \%$ and $0.6 \%$ of chicken and egg production, respectively, and only constitute a small fraction of the overall annual increase in demand. This suggests that policy reforms to facilitate the direct marketing of chickens and eggs do not have any noticeable effects on the conventional markets for these products. Such reforms also do not jeopardize the market stability that supply management is meant to protect.

Second, as Table 3 showed, the producer associations tend to adopt policy reforms that fit within the supply management framework by controlling the allocation of new permits and imposing various rules on new producers. For instance, permit holders are required to follow food safety and biosecurity regulations and, in some cases, must pay a fee to the producer association. In Quebec, program participants can even be prohibited from selling their products through certain marketing channels. Furthermore, permit holders are not recognized as members by the producer association managing the program, meaning they cannot take part in decisions or vote on proposals. As a consequence, the producers who own quotas and market their output through conventional supply chains continue to have the final say on how niche markets in local communities are developed.

\section{Conclusion}

Our objective in this study was to explore how rising demand for specialty products in short supply chains has created new challenges for Canada's supply management of egg, poultry, and dairy production. We note that new critics of the system are less focused on whether quotas are economically inefficient or entail higher costs for consumers. Instead, what is highlighted are the difficulties that the system currently faces in trying to accommodate niche-oriented farmers who wish to pursue direct marketing initiatives. Such producers tend to run smaller farms and often play a crucial economic and social role in rural development (Kneafsey et al., 2013; Martinez et al., 2010). Certainly, one of the main arguments for supply management is that it helps maintain the presence of farms across Canada. Nevertheless, the system is increasingly coming under criticism for impeding the development of farms (both new and established) that practice alternative forms of agriculture, that directly market specialty products, and that capitalize on their relational and geographic proximity to clients and local communities.

Our analysis of quota exemption limits and minimum quota requirements underscores the significant regulatory differences that exist between provinces in Canada. Paradoxically, the most restrictive rules can be found in the more urbanized provinces (British Columbia, Ontario, and Quebec), where a considerable number of farmers sell through short supply chains and benefit from access to large consumer markets. In contrast, the quota exemption limits are higher in the Prairie Provinces (Alberta, Manitoba, and Saskatchewan), where export-driven conventional farming is more widely practiced (Beingessner \& Fletcher, 2019). This is probably due to the fact that, in the more urbanized provinces, the strong growth of short supply chains is viewed as a potential problem, from both an economic and food safety perspective.

The three provinces presented (British Columbia, Ontario, and Quebec) all enacted reforms in response to growing pressure from small-scale, direct-market farmers who often struggle to grow their businesses due to their inability to obtain quotas. However, as we showed, the new programs involve strict production and, in some cases, marketing controls. Moreover, the proposals enacted so far will not, on their own, significantly improve the diversity of supply-managed products in Canada.

In conclusion, the results of our policy analysis suggest that the changes made to Canada's quota system have not eroded the regulatory powers of the provincial producer associations. While supply management policies have undeniably evolved in response to growing calls for reform from consumers, farmers, and advocacy groups, the reforms en- 
acted so far have yet to meaningfully promote greater food diversity. At the same time, supply management has proven to be an effective revenue protection tool for farmers and continues to be supported by most consumers. If the system can find additional ways to accommodate new entrants, develop niche markets in local communities, and promote food diversity, it will likely maintain its legitimacy in the eyes of Canadian consumers.

\section{Acknowledgments}

The authors would like to thank everyone who was contacted as part of this study, as well as the Center for Interuniversity Research and Analysis of Organizations (CIRANO) for its financial support. They also thank the reviewers for their suggestions and relevant comments.

\section{References}

Amir, S. (2014, July 22). Desperately wanted: Good chicken. National Post, p. A13. Retrieved from https://nationalpost.com/opinion/sefi-amir-desperately-wanted-good-chicken

Ballivy, V. (2012). L'attrait du beurre étranger [The lure of foreign butter]. La Presse. Retrieved from https://www.lapresse.ca/vivre/gourmand/cuisine/201205/02/01-4521109-lattrait-du-beurre-etranger.php

Barichello, R., Cranfield, J., \& Meilke, K. (2009). Options for the reform of supply management in Canada with trade liberalization. Canadian Public Policy, 35(2), 203-217. https://doi.org/10.3138/cpp.35.2.203

Beckie, M. A., Kennedy, E. H., \& Wittman, H. (2012). Scaling up alternative food networks: Farmers' markets and the role of clustering in western Canada. Agriculture and Human V alues, 29(3), 333-345. https://doi.org/10.1007/s10460-012-9359-9

Beingessner, N., \& Fletcher, A. J. (2019). "Going local": Farmers' perspectives on local food systems in rural Canada. Agriculture and Human V alues, 37, 1-17. https://doi.org/10.1007/s10460-019-09975-6

Blay-Palmer, A. D., Knezevic, I., Andrée, P., Ballamingie, P., Landman, K. E., Mount, P. A.,...\& Skinner, K. (2013). Future food system research priorities: A sustainable food systems perspective from Ontario, Canada. Journal of Agriculture, Food Systems, and Community Development, 3(4), 227-234. https://doi.org/10.5304/jafscd.2013.034.029

Boody, G., Vondracek, B., Andow, D. A., Krinke, M., Westra, J., Zimmerman, J., \& Welle, P. (2005). Multifunctional agriculture in the United States. BioScience, 55(1), 27-38. https://doi.org/10.1641/0006-3568(2005)055[0027:MAITUS]2.0.CO;2

Boston Consulting Group (2015). Analysis of the potential impacts of the end of supply management in the Canadian dairy industry. Retrieved from https://www.agropur.com/sites/default/files/documents/Analysis of \%20impacts of supply management Can adian dairy inudstry-EN.pdf

Boussard, J. M., Gerard, F., Piketty, M. G., Ayouz, M., \& Voituriez, T. (2006). Endogenous risk and long run effects of liberalization in a global analysis framework. Economic Modelling, 23(3), 457-475. https://doi.org/10.1016/j.econmod.2005.12.004

Bowler, I. R., \& Ilbery, B. W. (1999). Agricultural land-use and landscape change under the post-productivist transition: Examples from the United Kingdom. In R. Krönert, J. Baudry, I. R. Bowler, \& A. Reenberg (Eds.), Land-use changes and their environmental impact in rural areas in Europe (pp. 121-139). Paris: UNESCO and The Parthenon Publishing Group.

British Columbia Farm Industry Review Board (BCFIRB). (2005). Specialty market and new entrant submissions. Policy, analysis, principles and directions. Retrieved from https://www2.gov.bc.ca/gov/content/governments/organizationalstructure/ministries-organizations/boards-commissions-tribunals/bc-farm-industry-review-board/regulatedmarketing/supervisory-reviews/specialty-review-2005

Bryan Boyles \& Associates (2015). Allocating future growth consultations. Stakeholder consultation sponsored by Ontario Chicken Industry Advisory Committee. Retrieved from https://www.ontariochicken.ca/Good-Governance/Allocating-Growth-Solutions/Consultation-Reports.aspx

Campbell, A. M., \& MacRae, R. (2013). Local food plus: The connective tissue in local/sustainable supply chain development. Local Environment, 18(5), 557-566. https://doi.org/10.1080/13549839.2013.788488 
Cardwell, R., Lawley, C., \& Xiang, D. (2015). Milked and feathered: The regressive welfare effects of Canada's supply management regime. Canadian Public Policy, 41(1), 1-14. https://doi.org/10.3138/cpp.2013-062

Carter, C. A., \& Mérel, P. (2016). Hidden costs of supply management in a small market. Canadian Journal of Economics/Revue canadienne d'économique, 49(2), 555-588. https://doi.org/10.1111/caje.12206

Connell, D. J., Smithers, J., \& Joseph, A. (2008). Farmers' markets and the "good food" value chain: A preliminary study. Local Environment, 13(3), 169-185. https://doi.org/10.1080/13549830701669096

Csanady, A. (2015, October 7). Foodies unite! Supply management is the bane of the gourmand. National Post. Retrieved from http://news.nationalpost.com/full-comment/ashley-csanady-foodies-unite-supply-management-is-the-baneof-the-gourmand

Desrochers, P., Geloso, V., \& Moreau, A. (2018). Supply management and household poverty in Canada. International Review of Economics, 65(2), 231-240. https://doi.org/10.1007/s12232-018-0295-x

Doyon, M. (2011). Canada's dairy supply management: Comprehensive review and outlook for the future. Montreal, Canada: Center for Interuniversity Research and Analysis of Organizations. Retrieved from https://www.cirano.qc.ca/files/publications/2011DT-01.pdf

Doyon, M., Bergeron, S., \& Tamini, L. D. (2018). Milked and feathered: The regressive welfare effects of Canada's supply management regime: A comment. Canadian Public Policy, 44(3), 272-277. https://doi.org/10.3138/cpp.2017-044

Girouard, B. (2014). Toward supply management 2.0 in Canada. Lachute, Québec: Union Paysanne. Retrieved from http://archives.unionpaysanne.com/publications/Toward-Supply-Management-2-0-in-Canada.pdf

Goldfarb, D. (2009). Making milk: The practices, players, and pressures bebind dairy supply management. Ottawa: The Conference Board of Canada. Retrieved from https://conferenceboard.ca/temp/64172d25-910e-4ac0-8b27-5530c46b6dc4/10093 CanCompete MakingMilk.pdf

Gouel, C. (2010). Agricultural price instability: A survey of competing explanations and remedies. Journal of Economic Surveys, 26(1), 129-156. https://doi.org/10.1111/j.1467-6419.2010.00634.x

Gouin, D. M. (2001). Market-based regulation of milk quota transfer in Québec. In D. Barthélemy \& J. David (Eds.), Production rights in European agriculture (pp. 177-183). Paris: INRA Editions \& Elsevier. https://doi.org/10.1016/B978-044450823-2/50045-5

Gouin, D. M., \& Kroll, J. C. (2018). La régulation laitière face à la volatilité des marchés—États-Unis, Nouvelle-Zélande, Canada, France, Suisse [Dairy regulation in the face of market volatility-United States, New Zealand, Canada, France, Switzerland]. Économie Rurale, 364, 13-30. https://doi.org/10.4000/economierurale.5488

Graddy-Lovelace, G., \& Diamond, A. (2017). From supply management to agricultural subsidies—and back again? The US farm bill \& agrarian (in)viability. Journal of Rural Studies, 50, 70-83. https://doi.org/10.1016/i.jurstud.2016.12.007

Håkansson, A. (2015). What makes local food attractive to consumers? In A. Petrenko \& B. Müller-Hansen (Eds.), Interdisciplinary perspectives on local and regional food in the South Baltic Region (pp. 85-93). Kristianstad, Sweden: Kristianstad University Press.

Hall Findlay, M. (2012). Supply management: Problems, politics and possibilities. University of Calgary School of Public Policy Research Papers, 5(19), 12-19. https://doi.org/10.2139/ssm.2089041

Harvey, M., McMeekin, A., \& Warde, A. (Eds.). (2004). Qualities of food. Manchester, UK: Manchester University Press.

Hiscoks, G. (1972). Théorie et évolution de la réglementation du marché agricole au Canada [Theory and evolution of agricultural market regulation in Canada]. L'économie agricole an Canada, 7(2).

Katz, M., Bruneau, J. F., \& Schmitz, A. (2008). Identifying and applying a comparative advantage framework in Canadian supply-managed agriculture. Canadian Journal of Agricultural Economics/Revue canadienne d'agroeconomie, 56(2), 129-143. https://doi.org/10.1111/j.1744-7976.2008.00121.x 
Journal of Agriculture, Food Systems, and Community Development

ISSN: 2152-0801 online

https://www.foodsystemsjournal.org

Kneafsey, M., Venn, L., Schmutz, U., Balázs, B., Trenchard, L., Eyden-Wood, T.,...Blackett, M. (2013). Short food supply chains and local food systems in the EU. A state of play of their socio-economic characteristics. Luxembourg: European Commission. Retrieved from http://publications.jrc.ec.europa.eu/repository/bitstream/JRC80420/final \%20ipts \%20jrc\%2080420\%20(online).pdf

Laforge, J., Fenton, A., Lavalée-Picard, V., \& McLachlan, S. (2018). New farmers and food policies in Canada. Canadian Food Studies/La Revue canadienne des études sur l'alimentation, 5(3), 128-152. https://doi.org/10.15353/cfs-rcea.v5i3.288

Lamontagne, D. (2015). La ferme impossible [The impossible farm]. Montréal, Quebec: Éditions Écosociété.

Legendre, D. (2015, October 25). Pour un poulet différent au Québec [For a different chicken in Quebec]. Le Soleil. Retrieved from https://www.lesoleil.com/opinions/point-de-vue/pour-un-poulet-different-au-quebecc1c90857ecb9d3ae29ecca85b53b61f3

Martinez, S., Hand, M., Da Pra, M., Pollack, S., Ralston, K., Smith, T.,...Newman, C. (2010). Local food systems: Concepts, impacts, and issues. Washington, DC: US Department of Agriculture Economic Research Service. Retrieved from https://www.ers.usda.gov/webdocs/publications/46393/7054_err97_1_.pdf?v=42265

McIntyre, L., \& Rondeau, K. (2011). Individual consumer food localism: A review anchored in Canadian farmwomen's reflections. Journal of Rural Studies, 27(2), 116-124. https://doi.org/10.1016/j.jrurstud.2011.01.002

Ménard, M. (2015, February 2). Les fermiers de famille demandent plus de poules hors quotas [Family farmers are asking for more quota-free hens]. La Terre de chez nous. Retrieved from https://www.laterre.ca/actualites/alimentation/fermier-de-famille-demande-plus-de-poules-hors-quotas

Milone, P., \& Ventura, F. (2019). New generation farmers: Rediscovering the peasantry. Journal of Rural Studies, 65, 43-52. https://doi.org/10.1016/i.jrurstud.2018.12.009

Moreau, A. (2017). Trading supply management for softwood lumber? Montréal: Montreal Economic Institute. Retrieved from https://www.iedm.org/sites/default/files/pub files/note0317 en.pdf

Mount, P. (2017). Supply management as food sovereignty. In I. Knezevic, A. Blay-Palmer, C. Z. Levkoe, P. Mount, \& E. Nelson (Eds.), Nourishing communities: From fractured food systems to transformative pathways (pp. 147-164). New York: Springer.

Mount, P., Hazen, S., Holmes, S., Fraser, E., Winson, A., Knezevic, I.,...\& Landman, K. (2013). Barriers to the local food movement: Ontario's community food projects and the capacity for convergence. Local Environment, 18(5), 592-605. https://doi.org/10.1080/13549839.2013.788492

Muirhead, B. (2017). Re-ordering the rural? Canada, dairy supply management and the Trans-Pacific Partnership negotiations. In M. Miele, V. Higgins, H. Bjørkhaug, \& M. Truninger (Eds.), Transforming the rural: Global processes and local futures (pp.71-93). Bingley, UK: Emerald Publishing.

Mundler, P., Gouin, D.-M., Dominguez, S., Godefroy, S., Laughrea, S., \& Ubertino, S. (2017). Productions sans quota et commercialisation en circuits courts. Statut et enjeux [Production without quota and marketing in short circuits: Status and challenges]. Final report submitted to the CIRANO. Montréal: Université Laval. Retrieved from https://cirano.qc.ca/files/publications/2017RP-05.pdf

Mundler, P., \& Laughrea, S. (2016). The contributions of short food supply chains to territorial development: A study of three Quebec territories. Journal of Rural Studies, 45, 218-229. https://doi.org/10.1016/j.jrurstud.2016.04.001

Mundler, P., \& Ruiz, J. (2018). Industrie laitière. Gestion de l'offre et occupation du territoire [Dairy industry: Supply management and occupation of the territory]. In Y. Brousseau \& G. Mercier (Eds.), Le Québec d'une carte à l'autre Quebec from one map to another] (pp. 44-45). Québec: Presses de l'Université Laval.

Mussell, A. (2012). Does Canada need to dismantle supply management in the Trans-Pacific Partnership? Guelph, Canada: George Morris Centre. https://doi.org/10.22004/ag.econ.289969

Newman, L., Powell, L. J., Nickel, J., Anderson, D., Jovanovic, L., Mendez, E., Mitchel, B., Kelly-Freiberg, K. (2017). Farm stores in agriburbia: The roles of agricultural retail on the rural-urban fringe. Canadian Food Studies/La Revue canadienne des études sur l'alimentation, 4(1), 4-23. https://doi.org/10.15353/cfs-rcea.v4i1.211

Painter, M. J. (2007). A comparison of the dairy industries in Canada and New Zealand. Journal of International Farm Management, 4(1), 41-60. Retrieved from http://citeseerx.ist.psu.edu/viewdoc/download?doi=10.1.1.519.1364\&rep=rep1\&type=pdf 
Pearson, D., Henryks, J., Trott, A., Jones, P., Parker, G., Dumaresq, D., \& Dyball, R. (2011). Local food: Understanding consumer motivations in innovative retail formats. British Food Journal, 113(7), 886-899. https://doi.org/10.1108/00070701111148414

Régie des marchés agricoles et alimentaires du Québec (RMAAQ). (2017). Decision no. 11266, July 14, 2017.

Régie des marchés agricoles et alimentaires du Québec (RMAAQ). (2019). Decision no. 11658, July $22,2019$.

Richards, T. J. (1996). The effect of supply management on dairy productivity. The Canadian Journal of Economics/Revue canadienne d'Economique, 29, S458-S462. https://doi.org/10.2307/136087

Royer, A. (2008). The emergence of agricultural marketing boards revisited: A case study in Canada. Canadian Journal of Agricultural Economics/Revue canadienne d'agroeconomie, 56(4), 509-522.

https://doi.org/10.1111/j.1744-7976.2008.00144.x

Royer, A., Ménard, C., \& Gouin, D.-M. (2015). Reassessing marketing boards as hybrid arrangements: Evidence from Canadian experiences. Agricultural Economics, 47(1), 1-12. https://doi.org/10.1111/agec.12213

Ruiz, J., \& Parcerisas-Benede, L. (2017). 60 ans d'évolution, l'occupation agricole du territoire québécois sous la loupe (1951-2011) [60 years of evolution: The agricultural occupation of Quebec territory under the microscope (19512011)]. In: La ruralité au Québec depuis les états généraux du monde rural (1991): entre l'action et la recherche, bilan et perspectives [Rurality in Quebec since the Estates General of the Rural World (1991): Between action and research, assessment and perspectives] (pp. 130-155). Montreal, Canada: Chaire Desjardins. Retrieved from https://uqat.ca/chairedesjardins/medias/uploads/misc/Cahier Chaire Desjardins Acfas 2014.pdf

Ryan, J. (2013). Hutterites in Canada. The Canadian Encyclopedia. Retrieved from https://thecanadianencyclopedia.ca/en/article/hutterites

Schmitz, A. (2008). Canadian agricultural programs and policy in transition. Canadian Journal of Agricultural Economics/Revue canadienne d'agroeconomie, 56(4), 371-91. https://doi.org/10.1111/j.1744-7976.2008.00136.x

Schmitz, A., \& Schmitz, T. G. (1994). Supply management: The past and future. Canadian Journal of Agricultural Economics/Revue canadienne d'agroeconomie, 42(2), 125-148. https://doi.org/10.1111/j.1744-7976.1994.tb00013.x

Smithers, J., \& Joseph, A. E. (2010). The trouble with authenticity: Separating ideology from practice at the farmers' market. Agriculture and Human V alues, 27(2), 239-247. https://doi.org/10.1007/s10460-009-9250-5

Smithers, J., Lamarche, J., \& Joseph, A. E. (2008). Unpacking the terms of engagement with local food at the farmers' market: Insights from Ontario. Journal of Rural Studies, 24(3), 337-350. https://doi.org/10.1016/j.jrurstud.2007.12.009

Statistics Canada (2017a). Farms reporting selling agricultural products directly to consumers in the year prior to the census. Table: 32-10-0447-01. https://doi.org/10.25318/3210044701-eng

Statistics Canada (2017b). Production, disposition and farm value of poultry meat. Table: 32-10-0117-01. https://doi.org/10.25318/3210011701-eng

Statistics Canada (2017c). Production and disposition of eggs, annual. Table: 32-10-0119-01. https://doi.org/10.25318/3210011901-eng

Statistics Canada (2017d). Milk production and utilization. Table: 32-10-011301. https://doi.org/10.25318/3210011301-eng

Stewart, H., \& Dong, D. (2018). How strong is the demand for food through direct-to-consumer outlets? Food Policy, 79 , 35-43. https://doi.org/10.1016/j.foodpol.2018.04.010

Tamini, L. D., Doyon, M., \& Zan, M. M. (2018). Investment behavior of Canadian egg producers: Analyzing the impacts of change in risk aversion and in the variability of egg prices and production costs. British Food Journal, 120(1), 96107. https://doi.org/10.1108/BFJ-12-2016-0619

Thiele, S., \& Weiss, C. (2003). Consumer demand for food diversity: Evidence for Germany. Food Policy, $28(2), 99-115$. https://doi.org/10.1016/S0306-9192(02)00068-4

Van der Ploeg, J. D., Jingzhong, Y., \& Schneider, S. (2012). Rural development through the construction of new, nested, markets: Comparative perspectives from China, Brazil and the European Union. Journal of Peasant Studies, 39(1), 133173. https://doi.org/10.1080/03066150.2011.652619 
Veeman, M. M. (1982). Social costs of supply-restricting marketing boards. Canadian Journal of Agricultural Economics/Revue canadienne d'agroeconomie, 30(1), 21-36. https://doi.org/10.1111/j.1744-7976.1982.tb01962.x

Walker, H. V. (1968). Marketing boards and quota policies for Canadian farm products: An appraisal of performance. Canadian Journal of Agricultural Economics/Revue canadienne d'agroeconomie, 16(2), 1-12. https://doi.org/10.1111/j.1744-7976.1968.tb02424.x

Wittman, H., Beckie, M., \& Hergesheimer, C. (2012). Linking local food systems and the social economy? Future roles for farmers' markets in Alberta and British Columbia. Rural Sociology, 77(1), 36-61. https://doi.org/10.1111/j.1549-0831.2011.00068.x

Young, C., \& Watkins, M. (2010). New farmers and alternative markets within the supply-managed system. Toronto: Metcalf Foundation. Retrieved from https://metcalffoundation.com/site/uploads/2011/05/new-farmers-and-alternative-markets.pdf 